\title{
Competency-Based Learning: An Imperative Benchmark for Result Engendering Entrepreneurship Education
}

\author{
Dr. Giriraj Kiradoo ${ }^{1}$ \\ ${ }^{1}$ Associate Professor- Department of Management \& TechnologyGovt. Engineering College Bikaner, Rajasthan, \\ IN \\ 1'drgiriraj@hotmail.com
}

Article History: Received: 11 January 2021; Accepted: 27 February 2021; Published online: 5 April 2021

\begin{abstract}
Entrepreneurship is an essential element aiming to be part of this competitive world based on fostering economic growth, creativity, and innovation. The competency-based approach refers to mastering skills and abilities as per the internal will power instead of the external environment's pace. The present review dealt with studies that focused on entrepreneurship education, competence-based entrepreneurship learning, and a model curriculum. The program should identify and assess trainees' acquired competencies and develop a communication competency at the entrepreneurship training program's initial phase. Additionally, the entrepreneurship training programs' curriculum should develop the trainees' skills and capabilities. It should also focus on the industry-specific areas leading to economic growth. Hence there is a need to create quality courses by forming a committee of experts from various industries. It concluded that entrepreneurship training programs should develop specific competencies that enable the start-up founders to run their business successfully. Finally, the research considered enhancing motivation and attributes among trainees' entrepreneurial behaviour and increasing their satisfaction level.
\end{abstract}

Keywords: Competency-based learning, Entrepreneurship education, skills, abilities

\section{Introduction}

Entrepreneurship refers to the process of implementing the relevant skill, ability, and motivation towards a new business venture so that profit can be generated through risk-taking. It is also one of the critical elements for any nation aiming to be part of competition within the global market based on knowledge. It has created a more significant impact and interest in developing educational programs and encouraging them to initiate entrepreneurship programs (Boldureanu et al., 2020). However, there is no unanimity on whether entrepreneurship can be facilitated through education or not. However, this arrangement requires shifting the education system from the traditional pattern to an innovative and creative approach. The research is based on identifying the concept of competency-based learning in developing entrepreneurial skills and transforming the world through a reliable set of actions (European Commission, 2011). It will emphasize systematically conducted literature to gain a piece of in-depth knowledge about entrepreneurship development through competency-based learning. It will focus on the fact that competency-based education is based on emphasizing the multi-dimensional complications of issues.

Even though entrepreneurship training has gained global importance and interest, there is a lack in evaluating this program by high-profile policymakers. Thus, the impact of these programs on international knowledge remains narrow. It is often surprising that the event and running of courses and programs are expensive in cash and time for both participants and sponsors. Further, there is less research on entrepreneurs and training programs' essential needs. Therefore, this study addresses and assesses the entrepreneurs' training needs within an entrepreneurship educational program.

\section{Research methodology}

The research paper is based on secondary research to determine an in-depth understanding of the research topic. The research reviews various academic journals, books, and articles to gain insight into the research topic so that the origin, growth, and development of competency-based education in entrepreneurship can be derived. Various themes are used to gain an evaluation of the subject and comments of multiple authors. The literature published during the last few years will be reviewed to gain adequate information.

\section{Thematic analysis}




\section{THEME 1: CONCEPT OF ENTREPRENEURSHIP}

The phrase 'entrepreneurship' has derived as of the French phrase 'entreprendre', which implies 'to attempt or undertake'. Apart from entrepreneurship's origin, there is still no concrete definition of entrepreneurs and the essential requirement of any individual desire to become entrepreneurs. There are various viewpoints among the different fraternity on entrepreneurship. In simple terms, entrepreneurship is defined as initiating a new idea using relevant skill, knowledge, and ability. It places an innovative idea among the target market for profitability and success. In recent times, numerous programs are dealing with entrepreneurship and its aspects, focusing on various learning outcomes (van der Sijde et al., 2008). Thus, after going through multiple views on entrepreneurship, one can assume that entrepreneurship is the process wherein one identifies a unique and innovative business opportunity by collecting ideas and resources to create a corporation that will provide goods and services through imaginative perception (Byun et al., 2018). Through this approach, one can conclude that entrepreneurship focuses on creative opportunities and further introduces these opportunities to the market.

The author also focuses on another practical approach that visualizes entrepreneurship as a replacement company. Thus, entrepreneurs' central focus should be on collecting resources, especially finance, by promoting their innovative ideas to the investors who will pour in funds to convert an idea into a start-up company (van der Sijde et al., 2008). The entrepreneurial process is organized by the entrepreneur who absorbs and occupies the entrepreneurial behaviour to advance it further. However, the skills and behaviour any entrepreneur should have or possess grasping and acting on any opportunities that come their way, facing any issues, and solving them effectively, become a leader and take responsibility, create a network and develop a team besides using judgemental quality to calculate the jeopardies (Hannula \& Pajari-Stylman, 2008). All the above activitiesrelyupon the entrepreneur's proficiency, and entrepreneurship can thus be manifested by a pack of competencies (Onstenk, 2003). Besides, these texts will necessitate the assessment of the trainees and participants.

\section{THEME 2: ENTREPRENEURIAL COMPETENCIES}

Characteristics, talents, and expertise are three types of features that can be conceptually described as competency. In literature, these words are connected, which are derogative. Skills, on the other hand, have a wide variety of meanings, from broad to specific. Entrepreneurial competency is the sum of all critical characteristics for long-term growth and entrepreneurship, such as behaviours, ideals, beliefs, intelligence, talents, ability, personality qualities, experience, competence, and mental and behavioural patterns. Intellect is regarded as a distinct skill. The belief that concentrating on schooling can help people improve entrepreneurial skills is founded on the notion that entrepreneurial skills are malleable and can be learned in a limited amount of time. To put it another way, the most critical connections in learning entrepreneurship are the ones that are connected to experience, expertise, and attitudes (Byun et al., 2018). However, the above-discussed issues depict that despite networking, supporting, referring, and connecting with the associated businesses and projects, adequate support is not provided to the scholars who start their start-ups after graduating and completing the entrepreneurship course successfully (Boldureanu et al., 2020).

The concept and assessment of market prospects should be essential competencies in the early stages of a learner's entrepreneurial growth. Many other skills are also necessary for business success. Boyatzis model offers a basis for identifying certain entrepreneurial traits identified in entrepreneurship education, depending on which the form and degree of competencies can be known. Furthermore, the paradigm connects events that contribute to school disruption with appropriate levels of competence for learners. Since Boyatzis' model requires various degrees of competence, some of them are more adaptable than others. Intervention should be planned for the time constraints required for proficiency. As a result, the principle of competency opens up new avenues for intervention in entrepreneurship choice and training (Pont and Sonnet, 2003).

\section{THEME: 03 ENTREPRENEURSHIP LEARNING THROUGH FORMAL EDUCATIONAL COURSES AND TRAINING PROGRAMMES}

Learning definition also lacks consensus like entrepreneurship (Pont and Sonnet, 2003). However, the behaviourist visualizes it as a 'long-lasting change in behaviour resulting through continuous practice' (Atkinson, Atkinson, Smith \& Bem, 1993). The explanation pictured by behaviourist focuses on learning with three different aspects:

- The permanency of learning indicates that it has long-lasting nature. Thus, according to a behaviourist, knowledge that results from short-time changes is not included in this learning.

- Secondly, the learners' behaviour resulting from neurological and memorizing power. 
- The third and last aspect is the result obtained through continual practice. It characterizes the interaction of learning with the environment.

Finally, overall learning is viewed through cognition that helps impart permanent change within the learners' knowledge leading to behavioural change (Mayer, 2008). After behaviourist, constructivist views learn from interactions and experiences within the environment. However, there is a connection between past knowledge and recent learning experiences. These definitions' expected points include that learning leads to changes, irrespective of their behaviour, cognition, or understanding. Concerning competency-based education, the training program results in competencies such as cognitive skills (knowledge improvement), physical and behavioural skills, and practical attitude that embraces the definition of learning with the further addition of perspective. It is a process of competency gaining and advancement.

There have been required overall competencies such as agile behaviour, the creative and innovative mindset to build start-ups since the arrival of industry revolution 4.0. Consequently, most universities and institutions have begun to provide entrepreneurial training programs. These training programs' significant objectives are assumed to teach entrepreneurship and its importance. Therefore, training programs have increased policy support for entrepreneurship education in many countries (Walter and Block, 2016). Additionally, entrepreneurship education's interest and investment increase degree programs to extend thinking capacity. The importance of entrepreneurial training and education has increased tremendously among scholars and experts with innovative ideas and keen to gain business education. This training will impart the scholars with the required skills to achieve their goals through an increasingly diverse management environment.

The global experiment on entrepreneurship education (EE) and training (EET) have been conducted through various leaders and experts from national, regional, and international sectors. In current times, EET has been considered as a novel field for pursuing as a steppingstone for building one's own business or start-up. Thus, the EET program has been developed, keeping in mind the policymakers, experts, and students' interest. According to experts, EET is a whole concept, characterizing academics and formal training and learning. It shares the idea and objective of providing the students with mindsets and skills to build their entrepreneurial capabilities through various activities to support their participation. The program incorporates an assorted display and collection of activities and interventions such as educational schemes and independent learning and training courses. These kinds of EET programs aim to develop and stimulate the entrepreneurs and support all those start-ups, learners, individuals already working on their entrepreneurial start-ups. These include all the active entrepreneurs, conventional students enrolled in any university courses, adult trainees, rural and urban populations (Valerio et al., 2014).

\section{THEME: O4DEVELOPMENT OF ENTREPRENEURSHIP CURRICULUM AT SCHOOL AND UNIVERSITY STANDARD}

Further, entrepreneurship education also plays a crucial role in developing and emphasizing the entrepreneurs' insights. It provides them with the opportunities to initiate and work upon their ideas to build their own start-up company and manage them efficiently (Byun et al., 2018). Thus, universities have also worked upon their curriculum and emphasized building course structure on entrepreneurship. Some universities are actively working on spreading entrepreneurial education by including them in their development strategies. It enhances these courses' weightage and encourages students to inculcate entrepreneurship education and training. Also, several studies are organized to imbibe motivation, creative ideas and confidence among students pursuing entrepreneurship education. Another task incorporated through entrepreneurship education is developing a sense of social contribution (Coleman and Robb, 2012).

The primary role of entrepreneurship education comes out best in an uncertain situation. The program develops the visions and insights essential to creating entrepreneurs' opportunities. They also gain the power to successfully inaugurate their start-up company and manage it effectively (Daud et al., 2011). Therefore, the schools emphasize the need for entrepreneurship education in their curriculum that plays a crucial role in conducting and developing the professional entrepreneurship education training course. Apart from schools, universities also focus on developing programs based on entrepreneurial education as part of the more comprehensive strategy to enhance the effectiveness and standard of entrepreneurship curriculum as well as encourage students to pursue entrepreneurship education. Furthermore, many entrepreneurial courses and programs motivate students and imbibe confidence for business development and are socially active and contribute to society. Still, controversial issues and opinions about the appropriate approaches are teaching methodology or practical (Coleman and Robb, 2012). 


\section{THEME 5: EFFECTIVENESS OF ENTREPRENEURIAL EDUCATION AND TRAINING PROGRAMMES}

A grad school of entrepreneurship in Korea is managed and run by the government to deliver systematic, professional, and academic entrepreneurship teaching. The professional-grade school's objective is to encourage and support the start-ups and their experts capable of facing any situations and circumstances. The school's faculty provides training through a practical approach to their students for every stage required to develop their start-up easily differentiated from other existing business schools. The scholars who enrol in the entrepreneurship grad school are from varied background having a different purpose of attending the program. Evaluation of entrepreneurship curriculum and training programs encourages scholars' entrepreneurial attitudes and awareness. It increases their intention to start a start-up business.

Most of the studies on entrepreneurship training and education measure the entrepreneurship education training effectiveness by a degree of the entrepreneurs' intention (Millman et al., 2010). Further, to understand the difference between the entrepreneurship education programs among educators and students' perspective, one needs to research the entrepreneurship course's satisfaction level. It mostly enhances the knowledge and entrepreneurial skills after attending the well-structured and well-established entrepreneurship program and expertise.

The research on entrepreneurship education emphasizes designing the entrepreneurial program besides its implementation. Further, experts undertake the evaluation through objective practices, and students are thus poorly evaluated and addressed in this field (Pittaway et al., 2009). Here is also a scarcity of research on the effectiveness of entrepreneurship teaching program and its evaluation in degree courses. Byun et al. (2018) reported that the IPA analysis evaluated the primary curriculum to determine the entrepreneurship program's concept. It seeks opportunities, research feasibility, writing a business plan, accounting practicality, finance resources, and business marketing. Another essential subject in promoting the entrepreneurship curriculum includes venture finance, investments, and technology-based entrepreneurship. In contrast, topics like business growth strategy are not considered necessary within the entrepreneurial curriculum.

In the entrepreneurship program's effectiveness, it is crucial to form and collaborate with the alumni network, partner with external and recognized institutions, industries, and coach/mentor. It is often the reason for most of the students entering the school. It is also essential to be identified, attract more funds and educational support after completing the entrepreneurial course schemes. Therefore, it is vital to look for the event and directions for improvement to activate entrepreneurship education. In contrast, activities such as competitions, camps or training programs that are usually part of the entrepreneurship education curriculum are unnecessary.

The author suggests the following suggestions for reorganizing and improving entrepreneurship education.

\section{Personalities \& Competency Building}

Several entrepreneurship courses and training programs emphasize business owners' financial facets, such as planning a business or submitting proposals to potential investors. Alternatively, studies show that venture companies' success begins with an innovative attitude and risk-taking mind, such as high quality of self-efficiency, good interpersonal communication skills, well-balanced emotional intelligence are essential factors in its success. Therefore, entrepreneurship curriculum should develop these personalities and capabilities besides developing abilities.

The association between the education gained at university and the industry is essential to expand entrepreneurship education's quality and significance (Park et al., 2016). Analysis of business or start-ups and related cases helps understand the actual field experience.

Entrepreneurship education should focus on the industry's areas that lead to economic growth. Therefore, the educator or the trainer should prepare the curriculum by reflecting the changing of the economic environment and the students' requirements. This fluctuating economic environment further necessitates the importance of entrepreneurship education. It includes comprehensive market interest, opportunity, and discovery of students' capabilities from other faculties.

\author{
Align \\ Entrepreneurship \\ Curricula with \\ Industry's \\ Requirement
}




\section{Networking Appropriateness}

\section{Collaborate Guidance}

\begin{abstract}
Networking plays a critical role in small business and their success. The students and the graduates viewed networking expertise and skills as essential for their achievement. However, as an entrepreneur, one could also illustrate that it is essential to stimulate such educational programs to help and highlight a critical factor in entrepreneurial programs. Besides this, as the entrepreneurs have emphasized networking's appropriateness, social networking websites can help build and maintain relationships with business partners and alumni of the entrepreneurial schools who have started their business and are successful.
\end{abstract}

\begin{abstract}
Entrepreneurs require guidance and support from professionals who can provide them with input regarding the international perspective, given the market's global nature (Park et al., 2016). Worldwide awareness, knowledge, and proficiency are required to discover proficiencies like innovative and creative thinking, procurement, resource utilization, cross-cultural capabilities, and novel solutions to offset the problems. Entrepreneurship education should prioritize professional instructors' recruitment and various subjects' development. Besides, professionals, professors, and experts from multiple fields should collaborate and performcollectively to boost the program's excellence and build numerous courses.
\end{abstract}

\section{Conclusion}

The above research highlights that an increase in entrepreneurship acts as a catalyst for economic and social growth. It also fosters innovation, equity, growth and employment in an economy and helps create wealth. In today's environment, the high focus is on education in the field of entrepreneurship. The current entrepreneurship education process is criticized for not being as per the current economic and environmental standards. It is stated that education in entrepreneurship has highly become task-oriented and must increase its focus on developing skill that helps in handling the complexity of various issues. There is a clear gap between the actual knowledge and skill level of the student. Competency-based learning is an effective method in entrepreneurship to ensure that the necessary skills are developed among students as per their growth in education. The main advantage of competency-based learning in entrepreneurship is that it is a very flexible method, and the program depends upon the learner's ability. The course is self-paced; that is, the main focus is on improving the final outcome in terms of skill and knowledge instead of focusing on faster progress during the journey. One of the best facts is that this education method helps increase student engagement and is an affordable method of enhancing entrepreneurship interest.

The competency-based skill helps enhance the learners' managerial and entrepreneurial skills to compete effectively and achieve their goals. It is an effective method of training the founders of a business in creating and earning wealth through effective forms of formulation of program and courses in various fields. It is recommended that the curriculum and training activities in entrepreneurial development be designed as per the students' changing needs so that their skill development efficiently takes place. Further, the entrepreneurship training programs and the camps are organized to harmonize and link the alumni and scholars. Instead, qualified and successful entrepreneurs may be requested to deliver lectures and share experiences to enhance entrepreneurship education content and quality. Concerning the entrepreneurship-related programs, it is essential to supply support at various levels such as consulting by professionals or institutional consultation, support after graduation, support for community activation, and support for linking the existing business and professionals, but still, the satisfaction level of these programs is low.

\section{References}

1. Atkinson, R.L., Atkinson, S.C., Smith, E.E., Bem, D.J., 1993. Introduction to Psychology. Fort Worth: Harcourt Brace Jovanovich.

2. Boldureanu, G., Ionescu, A.M., Bercu, A.-M., Bedrule-Grigoruță, M.V., Boldureanu, D., 2020. Entrepreneurship Education through Successful Entrepreneurial Models in Higher Education Institutions. Sustainability 12, 1267. https://doi.org/10.3390/su12031267

3. Byun, C.-G., Sung, C., Park, J., Choi, D., 2018. A Study on the Effectiveness of Entrepreneurship Education Programs in Higher Education Institutions: a Case Study of Korean Graduate Programs. Journal of Open Innovation: Technology, Market, and Complexity 4, 26. https://doi.org/10.3390/joitmc4030026 
4. Coleman, S., Robb, A., 2012. Unlocking Innovation in Women-Owned Firms: Strategies for Educating the next Generation of Women Entrepreneurs. Journal of Women's Entrepreneurship and Education 1$2,99-125$.

5. Daud, S., Abidin, N., MazuinSapuan, N., Rajadurai, J., 2011. Enhancing University Business Curriculum Using an Importance-performance Approach. International Journal of Educational Management 25, 545-569. https://doi.org/10.1108/09513541111159059

6. Dickson, P.H., Solomon, G.T., Weaver, K.M., 2008. Entrepreneurial Selection and success: Does education matter? Journal of Small Business and Enterprise Development 15, 239-258. https://doi.org/10.1108/14626000810871655

7. European Commission, 2011. Entrepreneurship Education: Enabling Teachers as a Critical Success Factor. Entrepreneurship Unit, Europe, U.K.

8. Hannula, H., Pajari-Stylman, S., 2008. Entrepreneurship Incubators at HAMK University of Applied Sciences, in: van der Sijde, P., Ridder, A., Blaauw, G., Diensberg, C. (Eds.), Teaching Entrepreneurship. Physica-Verlag, Berlin/Heidelberg, pp. 77-89. https://doi.org/10.1007/978-3-79082038-6_8

9. Kiradoo, Giriraj, The Impact of E -Commerce in the Entrepreneurship and the Obstacles Faced by the Domestic Enterprise. International Journal of Management, 10 (5), pp. 154-164, 2019.

10. Kiradoo, Giriraj, Social Entrepreneurship and Their Roles and Responsibility Towards the Society and Challenges Faced in Profitable Organization. International Journal of Management, 10 (3), 2019, pp. 130-143, 2019.

11. Kiradoo, Giriraj, Entrepreneurship Factors Affecting the Economic Growth of a Nation. International Journal of Advanced Research in Engineering and Technology (IJARET), 9 (6), pp 236-240, 2018.

12. Kiradoo, Giriraj, Identifying and Evaluating the Factors Necessary for Promoting Entrepreneurship in a Country (June 2020). Journal of Critical Reviews, 07(13), 995-998, 2020.

13. Mayer, R.E., 2008. Learning and Instruction, 2nd ed. Upper Saddle River: Prentice Hall, N.J.

14. Millman, C., Li, Z., Matlay, H., Wong, W., 2010. Entrepreneurship Education and students' Internet Entrepreneurship Intentions. Journal of Small Business and Enterprise Development 17, 569-590. https://doi.org/10.1108/14626001011088732

15. Murugesan, R., Jayavelu, R., 2015. Testing the Impact of Entrepreneurship Education on business, Engineering and Arts and Science Students Using the Theory of Planned Behaviour. Journal of Entrepreneurship in Emerging Economies 7, 256-275. https://doi.org/10.1108/jeee-12-2014-0053

16. Onstenk, J., 2003. Entrepreneurship and Vocational Education. European Educational Research Journal 2, 74-89. https://doi.org/10.2304/eerj.2003.2.1.12

17. Park, J.-H., Lee, B., Moon, Y.-H., Kwon, L.-N., 2016. Study for Selection of Industrial Areas Suitable to Small and Medium-Sized Enterprises (SMEs) in Korea. Journal of Open Innovation: Technology, Market, and Complexity 2. https://doi.org/10.1186/s40852-016-0045-9

18. Pittaway, L., Hannon, P., Gibb, A., Thompson, J., 2009. Assessment Practice in Enterprise Education. International Journal of Entrepreneurial Behavior\& Research 15, 71-93. https://doi.org/10.1108/13552550910934468

19. Pont, B., Sonnet, A., 2003. Beyond rhetoric: adult learning policies and practices. OECD.

20. Valerio, A., Parton, B., Robb, A., 2014. Entrepreneurship Education and Training Programs around the World: Dimensions for Success. The World Bank. https://doi.org/10.1596/978-1-4648-0202-7

21. van der Sijde, P., Ridder, A., Blaauw, G., Diensberg, C., 2008. Teaching Entrepreneurship. Cases for Education and Training, research.utwente.nl. Physica-Verlag, Berlin/Heidelberg.

22. Walter, S.G., Block, J.H., 2016. Outcomes of Entrepreneurship education: an Institutional Perspective. Journal of Business Venturing 31, 216-233. 